\title{
Boštjan KERBLER
}

\section{Revitalisation of open spaces, changing centralities and neighbourhoods, and the importance of spatial planning for climate change adaptation}

This time around, Urbani izziv focuses on the importance of spatial planning for climate change adaptation, the revitalisation of parks and open spaces, the role of migrants in transforming urban neighbourhoods, the post-communist restructuring of centralities in central and eastern European capitals, gated communities and intergenerational living. The articles further develop selected findings from previous issues of the journal. A critical comparative analysis of these articles is presented below in order to provide added value to the articles and research findings published in this journal, and hence further enhance their research profile.

\section{Spatial planning during climate change}

In their article "Integration of extreme weather event risk assessment into spatial planning of electric power infrastructure," Maruša Matko et al. (2016) show how existing approaches or practices in land-use planning can be adjusted to take into account the results of risk assessment of gradual climate change. To better predict the impact of climate change, various combinations of climate change scenarios and scenarios of future energy and social development should be used. Amin Rastandeh (2015) also thinks along similar lines in his article "Challenges and potentials in using alternative landscape futures during climate change: A literature review and survey study," in which he focuses on the feasibility of applying alternative futures and scenario analysis in landscape planning during climate change. He too proposes using alternative futures and scenario analysis as an efficient tool supporting informed decisions on various policies and informing society of what the future might hold.

\section{Restructuring of post-communist cities}

In their article "Tracing post-communist urban restructuring: Changing centralities in central and eastern European capitals," Jasna Mariotti and Janez Koželj (2016) acknowledge that rapid political and economic changes after the collapse of communism led to dynamic processes of urban restructuring in cities, replacing old patterns and models of growth with ones in which capital and the market economy were central to growth and development. As part of these urban transformations, there were clear changes in location patterns of retail structures in cities, illustrating diverse patterns of post-communist cities' spatial organisation. The article "Evaluating issues and performance of a public transport network in a post-communist city using a quantitative spatial approach" by Lucian-Ionuț Roșu and Alexandra Blăgeanu (2015) also proceeds from the same findings. According to Roșu and Blăgeanu, the urban dynamics in eastern Europe after the fall of communism (seen as a consequence of the changes generated by the transition to a new ideology) have affected the local public services. This is also highlighted by Krzysztof Rogatka and Rodrigo Rudge 
Ramos Ribeiro (2015) in their article "A compact city and its social perception: A case study," in which they examine a Polish city in terms of the compact city concept.

Mariotti and Koželj (2016) further report that the formation of a market economy, the growing interests of real-estate developers and the planning initiatives of the municipalities neighbouring the capitals resulted in the emergence of low-density neighbourhoods with single-family homes, which was a desirable housing choice for many. These new settlement patterns impacted not only the housing market in cities, but also the social and spatial segregation of the city and its demographics, and contributed to problems of social exclusion. Similar conclusions were reached by Sasha Tsenkova in her article "The housing policy nexus and people's responses to housing challenges in post-communist cities," which appeared in Urbani izziv in 2014, and by Srna Mandič and Maša Filipovič Hrast in their 2015 article "Alternatives to social housing: Applicants' views of various policy options". The three authors explored the efforts to create a market-based housing system and competitive housing markets in the post-communist urban world. Their findings show that the transition in housing has exacerbated the initial differences in housing conditions, leading to significant affordability constraints, deterioration of privatised housing and a reduced share of social rental housing.

Furthermore, Mariotti and Koželj (2016) establish that, in parallel with these spatial restructuring processes, the city centre was losing its housing function, becoming more of an attraction than a living space. In this, they rely on the findings in Bálint Kádár's article "Differences in the spatial patterns of urban tourism in Vienna and Prague," which was published in this journal in 2013. According to Kádár, grocery stores and workshops in the city centre turn into souvenir shops and local pubs into fancy restaurants, and entire apartment buildings are converted into hotels because these are now more profitable services and businesses. Locals are generally disturbed by the overcrowded neighbourhoods and move out into suburbs or other parts of the city where parking, local services and tranquillity are more accessible. This resulting exodus produces a mono-functional city centre that loses its urban character through processes of "museumification" or "Disneyfication".

According to Mariotti and Koželj (2016), the changing patterns of centralities and the emergence of new spaces for consumerism are the most obvious signs of the move towards capitalism, a liberalised market, new politics and global trends in the urban transformations after communism. The newly emerged centralities are new social spaces, enlivened with an array of social activities, contributing to the cities' urban restructuring. In these newly established conditions, the opinion of city residents, who were largely excluded from public discussion and decision-making before the introduction of democratic changes, plays an important role in spatial planning. However, the inclusion of the public is a great challenge for spatial planners. This was already highlighted by Visar Hoxha et al. (2014) in their article "Cultural factors affecting urban planners' intentions to regulate public space in Prishtina" as well as by Špela Verovšek et al. (2013) in the article "Using visual language to represent interdisciplinary content in urban development: Selected findings". According to them, presenting and integrating ideas and using an interdisciplinary approach to spatial problems raise the issue of coordinating views and proposals by professionals and various public groups such as investors, the general public, governmental actors and so on. This was also confirmed by Aidan Cerar in his article "From reaction to initiative: Potentials of contributive participation," which was published in Urbani $i z z i v$ in 2014. 


\section{Revitalisation of parks and open spaces}

In their article "The revitalisation of parks and open spaces in downtown Johannesburg," Leani de Vries and Nico Kotze (2016) show that urban regeneration provides a solution to the problem of urban decay and that an important aspect of urban regeneration is to acknowledge the importance of green open spaces because they make cities more attractive. In addition, parks and open spaces serve the surrounding community with a multitude of functions and benefits. Hence, they are important considerations in attempts at urban regeneration that aim to assist decaying cities. This was already highlighted by several authors whose articles have been published in Urbani izziv: Nataša Bratina Jurković (2014), Ronnie Donaldson et al. (2014) and Andrej Pompe and Alenka Temeljotov Salaj (2014). For example, in her article "Perception, experience and the use of public urban spaces by residents of urban neighbourhoods," Bratina Jurković shows that taking into account the perception, experience, and use of urban spaces by residents of urban neighbourhoods is vital for successfully implementing user-friendly spatial planning. She reports that integrated open spaces allow residents and visitors to establish a strong connection between the environment and the user. In residential neighbourhoods, a sense of belonging and safety is developed by an individual. Hence, open spaces in residential neighbourhoods play a particularly important role because they should facilitate and encourage residents to socialise and connect. De Vries and Kotze (2016) also believe that parks and open spaces add to the aesthetic, historical and recreational value of the surrounding areas. In relation to memorial parks, this is also discussed by Marco Giliberti in his article "Rethinking the memorial in a Black Belt landscape: Planning, memory and identity of African-Americans in Alabama," which was published in this journal in 2013 and is based on an analysis of African-American historical sites. Giliberti reports that the memory of some historical sites is fading quickly, but it can be preserved by developing memorial parks, which also enhance local identity and strengthen the sense of community.

\section{The impact of migrants on transforming local neighbourhoods}

In their article "Migrants and the transformation of local neighbourhoods: A study of the socioeconomic transformation of Lidcombe, Australia," Franklin ObengOdoom and Hae Seong Jang (2016) highlight demographic, social and economic changes to emphasise the contribution of migrants to urban regeneration and to contest inherited stereotypes about migrants that often lead to racial scapegoating and misrepresentation. Their case study suggests that migrants can and often do transform the spaces they occupy in ways that make a positive and lasting contribution to the host economy and society more generally. The authors further establish that this negative sentiment is particularly acute in cities where pressure on amenities is concentrated and more visible. Consequently, migrant towns around the world are commonly described as spaces for criminals, illegal and dishonest activities, poor housing, blighted conditions, crime, grime and insecurity. In relation to informal settlements, some of these features have already been drawn attention to in Urbani izziv by Sasha Tsenkova (2014), Sophie Oldfield (2014), Ashley Gunter (2014), Lochner Marais (2014) and Akunnaya P. Opoko et al. (2015). In their article "Housing aspiration in an informal urban settlement: A case study," Opoko et al. explore the informal settlement of Ayobo in Lagos, Nigeria. They establish that the majority of its residents are low-income earners living in rented and rooming-house types of accommodation. They conclude that informal settlement housing remains 
a major challenge to sustainable urban growth and development. The article by Obeng-Odoom and Jang (2016) adds to the existing efforts to better understand migrant settlements. They focus on the Sydney suburb of Lidcombe, which migrants have transformed into a vibrant and diversified local economy with little crime and grime, and is thus an example of an overall positive socioeconomic transformation driven by migrants. Migrants have contributed to the transformation, but the transformation is simultaneously the town's Achilles' heel: property prices have increased substantially and hence Lidcombe is no longer the affordable neighbourhood that welcomed migrants and assisted them in achieving their "Australian dream". A similar gentrification-related issue in South Africa has already been highlighted by Nico Kotze (2013) in his article "A community in trouble? The impact of gentrification on the Bo-Kaap, Cape Town" and by Paul Tsietsi Monare et al. (2014) in their article "A second wave of gentrification: The case of Parkhurst, Johannesburg, South Africa". The "story" about the Bo-Kaap neighbourhood is especially interesting, having changed from a rundown neighbourhood into a trendy, sought-after area with much appeal for visitors. The number of properties sold is also on the rise - so much so that the community leaders and especially the Muslim residents are in a constant battle to preserve the neighbourhood's cultural identity.

\section{Residential areas with restricted access}

In their article "Are gated communities indispensable for residents?" Ayhan Bekleyen and İlham Yilmaz-Ay (2016) report that gated communities or residential areas with restricted areas have recently become widespread around the world. Their findings reveal high resident satisfaction levels and show that residents choose to live in these communities mainly because of safety and prestige. Residents' life quality can also be represented by their satisfaction levels. Higher satisfaction levels pertaining to the built environment may show a harmony between residents' actual situation and their preferred housing conditions, whereas lower satisfaction levels could indicate the opposite. This has already been discussed in Urbani izziv by Clinton Aigbavboa and Wellington Thwala (2014), Bijaya K. Shrestha (2013), John Gibson and Yanmei Li (2013), Yung Yau (2015), and Bojan Grum and Darja Kobal Grum (2015). In their article "A model of real estate and psychological factors in decision-making to buy real estate," Grum and Kobal report that people with a higher level of satisfied needs are more satisfied with their real estate and that people with a higher expression of the desire to gain recognition or better social status decide to buy real estate in order to improve their social status and prestige.

\section{Intergenerational living}

In their article "Intergenerational living: An intercultural comparison," Grum and Temeljotov Salaj (2016) explore the factors behind young adults living in shared households with their parents for an extended period of time. They proceed from the hypothesis that young and old living together as an extended family is not an indicator of intergenerational symbiosis and solidarity, but rather a reflection of wider social and cultural processes regulating the life of society as a whole and the lives of individuals. Their research confirmed their hypothesis and showed that, despite the fact that they get along relatively well, young people living in a shared household with their parents still want to "go it alone". As already indicated by Richard Sendi (2013) in his article "The low housing standard in Slovenia: Low purchasing power as an eternal excuse," overcrowding may cause uneasiness, health 
problems and so on, and so the government should take urgent action, taking into consideration new approaches to dwelling design that guarantee optimum modern housing standards. This is also confirmed by Grum and Temeljotov Salaj (2016), who report that young people expect greater help from the state through regulatory measures and fair distribution of social assistance between the "young" and the "old" generations to create social and housing policies that are fairer and friendlier to young families. This would reduce the pressure on the family and the potential for conflict within it, as well as the potential for conflict between the state and the family.

Boštjan Kerbler, Editor-In-Chief

Urban Planning Institute of the Republic of Slovenia, Ljubljana, Slovenia

E-mail: bostjan.kerbler@uirs.si

\section{References}

Aigbavboa, C. \& Thwala, W. (2014) Structural equation modelling of building quality constructs as a predictor of satisfaction in subsidised low-income housing. Urbani izziv, 25(supplement), pp. 134-147. DOI: 10.5379/urbani-izziv-en-en-2014-25-supplement-010

Bekleyen, A. \& Yilmaz-Ay, I (2016) Are gated communities indispensable for residents? Urbani izziv, 27(1), pp. 149-161. DOI: 10.5379/urbani-izziv-en-2016-27-01-005

Bratina Jurković, N. (2014) Perception, experience and the use of public urban spaces by residents of urban neighbourhoods. Urbani izziv, 25(1), pp. 107-125.

DOI: 10.5379/urbani-izziv-en-2014-25-01-003

Cerar, A. (2014) From reaction to initiative: Potentials of contributive participation. Urbani izziv, 25(1), pp. 93-106. DOl: 10.5379/urbani-izziv-en-2014-25-01-002

De Vries, L. \& Kotze, N. (2016) The revitalisation of parks and open spaces in downtown Johannesburg. Urbani izziv, 27(1), pp. 123-131. DOI: 10.5379/urbani-izziv-en-2016-27-01-003

Donaldson, R., Benn, J., Campbell, M. \& De Jager, A. (2014) Reshaping urban space through studentification in two South African urban centres. Urbani izziv, 25(supplement), pp. S176-S188.

Gibson, H. J. \& Li, Y. (2013) Opportunities for the United States condominium foreclosure market to provide amenable affordable housing options: The case of Tampa/Hillsborough, Florida. Urbani izziv, 24(1), pp. 90-106. DOI: 10.5379/urbani-izziv-en-2013-24-01-001

Giliberti, M. (2013) Rethinking the memorial in a Black Belt landscape: Planning, memory and identity of African Americans in Alabama. Urbani izziv, 24(1), pp. 144-159.

Grum, B. \& Kobal Grum, D. (2015) A model of real estate and psychological factors in decisionmaking to buy real estate. Urbani izziv, 26(1), pp. 82-91.

DOI: 10.5379/urbani-izziv-en-2015-26-01-002

Grum, B. \& Temeljotov Salaj, A. (2016) Intergenerational living: An intercultural comparison. Urbani izziv, 27(1), pp. 162-175. DOI: 10.5379/urbani-izziv-en-2016-27-01-006

Gunter, A. (2014) Renting shacks: Landlords and tenants in the informal housing sector in Johannesburg South Africa. Urbani izziv, 25(supplement), pp. 96-107.

DOI: 10.5379/urbani-izziv-en-en-2014-25-supplement-007

Hoxha, V., Dimitrovska Andrews, K. \& Temeljotov Salaj, A. (2014) Cultural factors affecting urban planners' intentions to regulate public space in Prishtina, Kosovo. Urbani izziv, 25(2), pp. 76-89. DOI: 10.5379/urbani-izziv-en-2014-25-02-001

Kádár, B. (2013) Differences in the spatial patterns of urban tourism in Vienna and Prague. Urbani izziv, 24(2), pp. 96-111. DOI: 10.5379/urbani-izziv-en-2013-24-02-002

Kotze, N. (2013) A community in trouble? The impact of gentrification on the Bo-Kaap, Cape Town. Urbani izziv, 24(2), pp. 114-132. DOI: 10.5379/urbani-izziv-en-2013-24-02-004

Mandič, S. \& Filipovič Hrast, M. (2015) Alternatives to social housing: Applicants' views of various policy options. Urbani izziv, 26(1), pp. 69-81. DOI: 10.5379/urbani-izziv-en-2015-26-01-001

Marais, L., Ntema, J., Cloete, J. \& Venter, A. (2014) From informality to formality to informality: Extralegal land transfers in an upgraded informal settlement of South Africa. Urbani izziv, 25(supplement), pp. S148-S161. DOI: 10.5379/urbani-izziv-en-en-2014-25-supplement-011 
Mariotti, J. \& Koželj, J. (2016) Tracing post-communist urban restructuring: Changing centralities in central and eastern European capitals. Urbani izziv, 27(1), pp. 113-122.

DOI: 10.5379/urbani-izziv-en-2016-27-01-002

Matko, M., Golobič, M. \& Kontić, B. (2016) Integration of extreme weather event risk assessment into spatial planning of electric power infrastructure. Urbani izziv, 27(1), pp. 95-112.

DOI: 10.5379/urbani-izziv-en-2016-27-01-001

Obeng-Odoom, F. \& Jang, H. S. (2016) Migranti in preobrazba sosesk: raziskava družbenogospodarske preobrazbe sydneyjskega predmestja Lidcombe. Urbani izziv, 27(1), pp. 132-148. DOI: 10.5379/urbani-izziv-en-2016-27-01-004

Oldfield, S. (2014) Intertwining lives and logics: Household and informal economies in Cape Town. Urbani izziv, 25(supplement), pp. S36-S46.

DOI: 10.5379/urbani-izziv-en-en-2014-25-supplement-003

Opoko, A. P., Ibem, E. O. \& Adeyemi, E. A. (2015) Housing aspiration in an informal urban settlement: A case study. Urbani izziv, 26(2), pp. 117-131. DOI: 10.5379/urbani-izziv-en-2015-26-02-003

Pompe, A. \& Temeljotov Salaj, A. (2014) Qualitative criteria of urbanism and brands: A comparative analysis. Urbani izziv, 25(1), pp. 74-92. DOl: 10.5379/urbani-izziv-en-2014-25-01-001

Rastandeh, A. (2015) Challenges and potentials in using alternative landscape futures during climate change: A literature review and survey study. Urbani izziv, 26(2), pp. 83-102.

DOI: 10.5379/urbani-izziv-en-2015-26-02-001

Rogatka, K. \& Ramos Ribeiro, R. R. (2015) A compact city and its social perception: A case study. Urbani izziv, 26(1), pp. 121-131. DOI: 10.5379/urbani-izziv-en-2015-26-01-005

Roșu, L-I. \& Blăgeanu, A. (2015) Evaluating issues and performance of a public transport network in a post-communist city using a quantitative spatial approach. Urbani izziv, 26(2), pp. 103-116. DOI: 10.5379/urbani-izziv-en-2015-26-02-002

Sendi, R. (2013) The low housing standard in Slovenia: Low purchasing power as an eternal excuse. Urbani izziv, 24(1), pp 107-124. DOI: 10.5379/urbani-izziv-en-2013-24-01-002

Shrestha, B. K. (2013) Residential neighbourhoods in Kathmandu: Key design guidelines. Urbani izziv, 24(1), pp. 125-143. DOI: 10.5379/urbani-izziv-en-2013-24-01-003

Tsenkova, S. (2014) The housing policy nexus and people's responses to housing challenges in post-communist cities. Urbani izziv, 25(2), pp. 90-106.

DOI: 10.5379/urbani-izziv-en-2014-25-02-002

Verovšek, S., Juvančič, M. \& Zupančič, T. (2013) Using visual language to represent interdisciplinary content in urban development: Selected findings. Urbani izziv, 24(2), pp. 144-155. DOI: 10.5379/urbani-izziv-en-2013-24-02-006

Yung, Y. (2015) The value of building safety: A hedonic price approach. Urbani izziv, 26(1), pp. 92-104. DOI: 10.5379/urbani-izziv-en-2015-26-01-003 